\title{
Herpes virus in juvenile Pacific oysters Crassostrea gigas from Tomales Bay, California, coincides with summer mortality episodes
}

\author{
Carolyn S. Friedman ${ }^{1, *}$, Robyn M. Estes ${ }^{1}$, Nancy A. Stokes ${ }^{2}$, Colleen A. Burge ${ }^{1}$, \\ John S. Hargove ${ }^{1}$, Bruce J. Barber ${ }^{3,5}$, Ralph A. Elston ${ }^{4}$, Eugene M. Burreson ${ }^{2}$, \\ Kimberly S. Reece ${ }^{2}$ \\ ${ }^{1}$ School of Aquatic and Fishery Sciences, University of Washington, PO Box 355020, Seattle, Washington 98195, USA \\ ${ }^{2}$ Virginia Institute of Marine Science, The College of William and Mary, Gloucester Point, Virginia 23062, USA \\ ${ }^{3} 340$ Hitchner Hall, University of Maine, Orono, Maine 04469, USA \\ ${ }^{4}$ Pacific Shellfish Institute, PO Box 687, Carlsborg, Washington 98324, USA \\ ${ }^{5}$ Present address : Department of Marine Science, Eckerd College, 4200 54th Ave S, St. Petersburg, Florida 33711, USA
}

\begin{abstract}
Pacific Crassostrea gigas and eastern C. virginica oysters were examined between June 2002 and April 2003 from 8 locations along the east, west and south USA coasts for oyster herpes virus (OsHV) infections using the A primer set in a previously developed PCR test. Only surviving Pacific oysters from a mortality event in Tomales Bay, California, USA, where annual losses of oysters have occurred each summer since 1993, were infected with a herpes-like virus in 2002. PCR examination using template amounts of both 50 and $500 \mathrm{ng}$ were essential for OsHV detection. Sequence analysis indicated that the Tomales Bay OsHV was similar to that identified in France with the exception of a single base pair substitution in a 917 bp fragment of the viral genome. However, unlike the French OsHV-1, the Tomales Bay OsHV did not amplify with the primer pair of a second OsHV-1 PCR assay, suggesting that further characterization of these viruses is warranted. No evidence of Cowdry type A viral infections characteristic of herpes virus infections or other pathogens were observed in OsHVinfected oysters. Hemocytosis, diapedesis and hemocyte degeneration characterized by nuclear pycnosis and fragmentation were observed in infected oysters, which is consistent with previous observations of OsHV infections in France. Together these data suggest that OsHV may be associated with the annual summer Pacific oyster seed mortality observed in Tomales Bay, but establishment of a causal relationship warrants further investigation.
\end{abstract}

KEY WORDS: Pacific oyster $\cdot$ Herpes virus $\cdot$ Mortality $\cdot$ Tomales Bay $\cdot$ California

\section{INTRODUCTION}

Herpes-like viral infections were first reported in the eastern oyster Crassostrea virginica Gmelin in 1972 from the east coast of the USA (Farley et al. 1972). In 1991 in New Zealand and in 1992 in France, larval Pacific oysters $C$. gigas Thunberg were reported with herpes-like viral infections (Hine et al. 1992, Nicolas et al. 1992) that caused significant mortality. More limited evidence suggests that herpes-like viruses may infect and kill juvenile oysters, but the pathological effects of the virus on juveniles are not well documented. Since that time, larval Pacific oyster losses have recurred annually in France and adjacent countries during the summer months (Renault et al. 1994a,b, 2000b). The same or similar herpes-like virus(es) has been reported in other oyster species including flat oysters Ostrea angasi and Ostrea chilensis in Australia and New Zealand (Hine \& Thorne 1997, Hine et al. 1998) and Ostrea edulis in France (Renault et al. 2000b). Other 
bivalve species including manila clams Venerupis (=Ruditapes) philippinarum and Suminoe oysters Crassostrea rivularis $(=C$. ariakensis) are also susceptible to herpes-like viral infection (Arzul et al. 2001, Renault et al. 2001). Both intra- and inter-specific transmission of the virus have been demonstrated (Le Deuff et al. 1994, Arzul et al. 2001). Davison (2002) demonstrated that the French OsHV is a member of the family Herpesviridae and suggested that the apparent lack of host specificity of OsHV is unique among members of this family.

Seasonal and severe losses of juvenile Pacific oysters have occurred annually in Tomales Bay, California, USA, between mid-April and mid-October beginning in 1993 and appear to be associated with elevated spring and summer water temperatures (Cherr \& Friedman 1998, Righetti 2002). Multiple environmental stressors have been investigated as possible causes of these losses but no definitive explanation has yet been found. In the process of conducting a national survey for the presence of oyster herpes-like virus (OsHV), and cognizant of the association of OsHV productive infections with temperatures of 25 to $26^{\circ} \mathrm{C}$ (Le Deuff et al. 1994, 1996), we included a preliminary investigation for the presence of OsHV in Tomales Bay, California. We examined the distribution of this virus in the USA using the PCR primers developed by Renault et al. (2000a) and Renault \& Arzul (2001).

\section{MATERIALS AND METHODS}

Oysters. Pacific oyster larvae and seed were collected from 4 locations along the US west coast between June 2002 and April 2003 (Table 1). Up to 5 groups of juvenile (0 year class) Pacific oysters (4 diploid and 1 triploid group) were examined at these sites. The seed oysters were produced by the Molluscan Broodstock Program of Oregon State University ( $\mathrm{n}=2$ lines: OR-1 and OR-2) and 2 commercial farms in Washington State ( $\mathrm{n}=3$ lines: WA-1, WA-2-2N and WA-3-3N) in the late winter of 2002. Juvenile oysters ( $<1 \mathrm{~cm}$ in shell height) from each cohort were planted in $0.64 \mathrm{~cm}$ mesh oyster culture bags simultaneously in California (Tomales Bay) and Washington state (Totten Inlet) in the spring of 2002. Commercially cultured eastern oysters from Grand Terre, Louisiana, Fort Pierce, Florida, Gloucester Point, Virginia, and Muscongus Bay, Maine, were also examined (Table 1). Larvae and spat were either preserved in $95 \%$ ethanol for storage until DNA extraction or tissues were excised for immediate DNA extraction (see below). Larvae were pooled in aliquots of 1 to $2 \mathrm{ml}$ and spat were pooled ( 3 to 10 per group) until evidence of OsHV was found, after which oysters were sampled individually.
Groups of 30 juvenile oysters from each family were removed from individual mesh bags and the percentage of live versus dead juvenile oysters was enumerated by calculating the number of dead individuals (gaping oysters or empty shells). All west coast samples were processed at the University of Washington (UW) and all east and Gulf Coast samples were processed at the Virginia Institute of Marine Science (VIMS). Any OsHV PCR-positive sample was sent to the alternate laboratory for confirmation.

Histology. A standard cross section that included mantle, gills, gonad and digestive tissues was excised ventral to the labial palps from all oysters at each sampling site, placed in invertebrate Davidson's solution (Shaw \& Battle 1957) and processed for routine paraffin histology. Deparaffinized $5 \mu \mathrm{m}$ tissue sections from a subset of oysters that were PCR positive for the OsHV were stained with hematoxylin and eosin (Luna 1968) and viewed by light microscopy to characterize morphological changes within these individuals. We were particularly interested in determining if herpes-like intranuclear inclusion bodies or other lesions that might be related to OsHV infection could be found.

Nucleic acid extraction. Initially, samples were processed for nucleic acid extraction according to the methods of Renault et al. (2000a). Briefly, oyster tissues were homogenized in a Tenbrook homogenizer in distilled $\mathrm{H}_{2} \mathrm{O}\left(0.1 \mathrm{~g}\right.$ tissue $\left.\mathrm{ml}^{-1} \mathrm{dH}_{2} \mathrm{O}\right)$ and incubated in a boiling water bath for $10 \mathrm{~min}$. Samples were then mixed and centrifuged at $9000 \times g$ for $10 \mathrm{~min}$. The supernatant was collected and stored at $-20^{\circ} \mathrm{C}$. DNA quality was poor in these samples as evidenced by gel electrophoresis, and nucleic acid was extracted from subsequent samples using the QIAamp DNA Mini Kit (Qiagen) according to the manufacturer's protocol.

Polymerase chain reaction. Herpes-like virus: Positive control OsHV DNA was provided by T. Renault (IFREMER, La Tremblade, France). We employed the primers and PCR test conditions of Renault et al. (2000a) and Renault \& Arzul (2001) (primers A3/A4, $\mathrm{A} 5 / \mathrm{A} 6$ and $\mathrm{C} 2 / \mathrm{C} 6)$. Briefly, each $20 \mu \mathrm{l}$ reaction contained 10× PCR buffer (10 mM Tris, $\mathrm{pH} 8.3 ; 50 \mathrm{mM}$ $\mathrm{KCl}), 2.5 \mathrm{mM} \mathrm{MgCl} \mathrm{Mg}_{2}, 8 \mu \mathrm{gSA}, 0.2 \mathrm{mM}$ dNTP mix, 4 pmol each primer, 1 U Taq polymerase (Promega) and $0.4 \mu \mathrm{l}$ of template DNA. Following amplification with primers $\mathrm{A} 3 / \mathrm{A} 4,0.4 \mu \mathrm{l}$ of the reaction mixture was added to the A5/A6 reaction mixture for the nested reaction.

Duplicate nucleic acid amplifications were performed with an initial denaturation step at $94^{\circ} \mathrm{C}$ for $2 \mathrm{~min}$, followed by 35 cycles at $94^{\circ} \mathrm{C}$ for $1 \mathrm{~min}, 50^{\circ} \mathrm{C}$ for $1 \mathrm{~min}$, and $72^{\circ} \mathrm{C}$ for $1 \mathrm{~min}$, with a final elongation at $72^{\circ} \mathrm{C}$ for $5 \mathrm{~min}$. Products were separated on $1.0 \%$ agarose gels containing $0.1 \mathrm{\mu g} \mathrm{ml}^{-1}$ ethidium bromide and visualized using a UV transilluminator. The nested 
PCR primers first amplify a $1001 \mathrm{bp}$ fragment (primers A3/A4) and then a 917 bp fragment (primers A5/A6) of the oyster herpes virus genome. Primers C2/C6 amplify a $710 \mathrm{bp}$ fragment from a different region of the viral genome. SigmaStat 2.0 was used for a Pearson's Product Moment Correlation to test if a linear relationship existed between the prevalence of PCRpositive samples and percent mortality in 4 of the oyster lines examined in Tomales Bay and cohorts examined from Totten Inlet.

PCR optimization: The use of standard template volumes in PCR tests can yield varying results due to differences in template DNA extracted from tissues. We quantified the optimal amount of template DNA for the PCR tests using the reaction conditions stated above and 50,100,150, 200, 400, 600 and $800 \mathrm{ng}$ of template DNA. All reactions were conducted in duplicate. Once optimized, all subsequent PCR tests and all samples previously tested with negative or inconsistent results were (re-)examined using both a reaction with the standard $1 \mu$ l volume employed by Renault et al. (2000a), which resulted in a mean of $\sim 50 \mathrm{ng}$ of template, as well as a reaction with $500 \mathrm{ng}$ of template nucleic acid per reaction. A subset of 60 samples from the October 2002 survey date was thus examined using both 50 and $500 \mathrm{ng}$ of template. In addition, as the concentration of nucleic acid extracted from oyster tissues varied between samples (from $<50$ to $806 \mathrm{ng} \mathrm{ml}^{-1}$ ), a group of 89 samples was examined using both $1 \mu \mathrm{l}$ and $500 \mathrm{ng}$ of template DNA in the PCR tests.

Universal SSU genes: To assure that amplifiable DNA was present in all samples, nucleic acid from all samples negative for OsHV by PCR was tested using universal small subunit (SSU) ribosomal RNA gene primers. We employed the primers and adapted the conditions of Le Roux et al. (1999) (Fig. 1B: primers CS1 and CAS1). Briefly, each $20 \mu$ reaction contained 10× PCR buffer (10 mM Tris, pH 8.3; $50 \mathrm{mM} \mathrm{KCl),}$ $2.5 \mathrm{mM} \mathrm{MgCl}_{2}, 8 \mu \mathrm{g}$ BSA, $0.2 \mathrm{mM}$ dNTP mix, $10 \mathrm{pmol}$ each primer, $1 \mathrm{U}$ Taq polymerase (Promega) and $0.4 \mu \mathrm{l}$ of template DNA. Nucleic acid amplifications were performed with an initial denaturation step at $94^{\circ} \mathrm{C}$ for 5 min, followed by 30 cycles at $94^{\circ} \mathrm{C}$ for $1 \mathrm{~min}, 55^{\circ} \mathrm{C}$ for $1 \mathrm{~min}$, and $72^{\circ} \mathrm{C}$ for $1 \mathrm{~min}$, with a final elongation at $72^{\circ} \mathrm{C}$ for $10 \mathrm{~min}$. PCR products were separated and visualized in the manner mentioned above with an expected product size of $810 \mathrm{bp}$.

Sequence of the OsHV amplicons. In order to confirm the PCR results, selected samples were amplified, cloned and sequenced by both laboratories. In addition to the PCR products from Tomales Bay, PCR products from OsHV genomic DNA from France amplified with primers A3/A4 and C2/C6 were also cloned and sequenced. PCR products from triplicate reactions for each sample were pooled and purified (Concert PCR
Purification System, Life Technologies), ligated into the plasmid vector pCR2.1 from the TA Cloning Kit (Invitrogen), and transformed into Escherichia coli INV $\alpha F^{\prime}$ cells following the manufacturer's protocol. Amplification products from 12 PCR-positive samples collected in June and October from Tomales Bay oysters were cloned following pooling and purification of triplicate reactions into either pCR2.1 or pCR4-TOPO cloning vectors using either the TA Cloning Kit or the TOPO TA Cloning Kit for sequencing according to the manufacturer's instructions (Invitrogen). Recombinant plasmids were isolated from individual transformed colonies by using either an alkaline lysis miniprep (Sambrook et al. 1989) or the QIAprep Spin Miniprep kit (Qiagen) and were screened for the presence of insert-containing plasmids by performing PCR using the M13 primers supplied with the kit as well as ECo RI digestion of the plasmid. Plasmids containing amplification products yielded 2 DNA bands of approximately 1000 and $4000 \mathrm{bp}$ for the A5/A6 PCR product insert and vector, respectively.

At the UW, 1 clone from each of 5 individual Pacific oysters was sequenced with the DYEnamic ET Dye Terminator Cycle Sequencing Kit for MegaBACE (Amersham Pharmacia Biotech) according to the manufacturer's instructions. Following the cycle sequencing protocol, DNA was precipitated with a mixture of 7.5 M ammonium acetate and $100 \%$ ethanol. Sequencing reactions were analyzed using a MegaBACE 1000 sequencer and software at the UW Marine Molecular Biotechnology Laboratory. Each strand of the OsHV DNA was sequenced using forward and reverse primers to check sequencing accuracy. The pCR4 vector primers (M13F and M13R) from the TOPO TA Cloning Kit for Sequencing were used. The sequences were assembled using the Sequencher computer program (version 4.0.5, Gene Codes Corporation). The DNA sequences were subjected to BLAST searches (Altschul et al. 1990) of the National Center for Biotechnology Information (NCBI) GenBank database and aligned to available oyster herpes virus sequences (Renault et al. 2000a) to confirm their identity.

At VIMS, cloned samples were cycle sequenced using the ThermoSequenase kit (Amersham Pharmacia) and M13 forward and reverse primers labeled with the fluorescent dyes IRD-700 and IRD-800 (LI-COR) in simultaneous bidirectional sequencing. Sequencing reactions were electrophoresed on $41 \mathrm{~cm} 5.5 \%$ polyacrylamide gels in a LI-COR Model 4200 automated sequencer. Two to 3 clones for each of 7 Tomales Bay Crassostrea gigas samples were sequenced and 6 clones each for A and C fragments amplified from the French OsHV-1 were sequenced. Consensus sequences for the A5/A6 PCR fragment from Californian OsHV, the A3/A4 PCR fragment from French OsHV-1, 
and the C2/C6 PCR fragment from French OsHV-1 were generated using the MacVector 7.0 DNA sequence analysis software package (Oxford Molecular) and then assigned GenBank accession numbers AY459362, AY459363 and AY459364.

\section{RESULTS}

\section{Survey}

Only oysters from Tomales Bay, California, yielded PCR evidence of herpes-like virus infection (Table 1). These PCR-positive samples amplified with the nested A primer set (917 bp product; Table 1); however, they did not generate product with the $\mathrm{C}$ primer pair (Table 1). Oyster samples from all locations yielded amplifiable DNA, as evidenced by the 810 bp product generated with SSU rDNA control primers. The prevalence of OsHV from individual oysters was detected in surviving members of oyster families in Tomales Bay and roughly correlated with percent mortality for the respective family during the October 2002 sampling (Fig. 1). The group with the lowest number of dead oysters in the sample $(2 \%$; WA- 1$)$ had the lowest

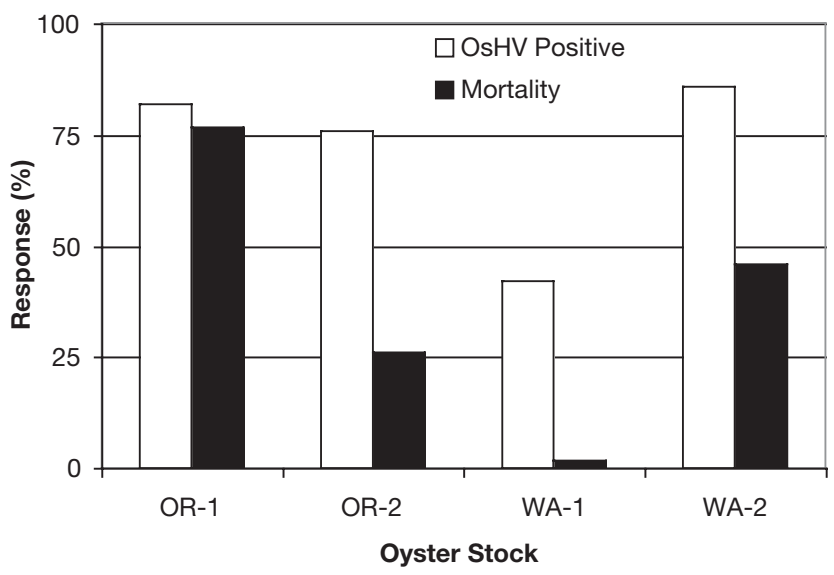

Fig. 1. Differential mortality observed in October 2002 within 4 groups of Pacific oysters from Tomales Bay, California, USA (black bars), in relation to oyster herpes-like virus (OsHV) infection (white bars) based on the total percent PCR positive using either $1 \mu \mathrm{l}$ and/or $500 \mathrm{ng}$ of oyster template DNA

Table 1. Sample schedule and results of PCR analysis of excised tissues. nd: not determined. Note: the presence of amplifiable DNA was confirmed in all samples using the $18 \mathrm{~S}$ rDNA PCR reaction; data not shown

\begin{tabular}{|c|c|c|c|c|c|}
\hline Site & Stock & $\begin{array}{c}\text { Sample } \\
\text { date } \\
\text { (mo/yr) }\end{array}$ & $\begin{array}{l}\text { Number } \\
\text { tested }\end{array}$ & $\begin{array}{c}\% \text { positive } \\
\text { with A- } \\
\text { primers }\end{array}$ & $\begin{array}{l}\% \text { positive } \\
\text { with C- } \\
\text { primers }\end{array}$ \\
\hline Totten Inlet, Washington & $\begin{array}{c}\text { WA-2-2N } \\
\text { OR-1 } \\
\text { OR-2 }\end{array}$ & $\begin{array}{r}6 / 02 \\
11 / 02 \\
11 / 02\end{array}$ & $\begin{array}{c}5 \\
30 \\
30\end{array}$ & $\begin{array}{l}0 \\
0 \\
0\end{array}$ & $\begin{array}{l}\text { nd } \\
\text { nd } \\
\text { nd }\end{array}$ \\
\hline Dabob Bay, Washington & $\begin{array}{c}\text { OR-2 } \\
\text { OR-3 } \\
\text { OR-4 } \\
\text { OR-5 } \\
\text { WA-2-2N }\end{array}$ & $6 / 02$ & 20 & $\begin{array}{l}0 \\
0 \\
0 \\
0 \\
0\end{array}$ & $\begin{array}{l}\text { nd } \\
\text { nd } \\
\text { nd } \\
\text { nd } \\
\text { nd }\end{array}$ \\
\hline Yaquina Bay, Oregon & $\begin{array}{l}\text { OR-3 } \\
\text { OR-4 } \\
\text { OR-5 } \\
\text { OR-6 }\end{array}$ & $\begin{array}{l}4 / 03 \\
4 / 03 \\
4 / 03 \\
7 / 02\end{array}$ & $\begin{array}{c}30^{\mathrm{a}} \\
30^{\mathrm{a}} \\
30^{\mathrm{a}} \\
10\end{array}$ & $\begin{array}{l}0 \\
0 \\
0 \\
0\end{array}$ & $\begin{array}{l}\text { nd } \\
\text { nd } \\
\text { nd } \\
\text { nd }\end{array}$ \\
\hline Tomales Bay, California & $\begin{array}{c}\text { OR-1 } \\
\text { OR-2 } \\
\text { OR-1 } \\
\text { OR-2 } \\
\text { WA-1 } \\
\text { WA-2-2N }\end{array}$ & $\begin{array}{r}6 / 02 \\
6 / 02 \\
10 / 02 \\
10 / 02 \\
10 / 02 \\
10 / 02\end{array}$ & $\begin{array}{l}30^{\mathrm{b}} \\
30^{\mathrm{b}} \\
11 \\
29 \\
30 \\
29\end{array}$ & $\begin{array}{c}0 \\
70 \\
18^{\mathrm{c}}, 72^{\mathrm{d}} \\
37,46 \\
3,37 \\
67,45\end{array}$ & $\begin{array}{l}0 \\
0 \\
0 \\
0 \\
0 \\
0\end{array}$ \\
\hline Grande Terre, Louisiana & LA-1 & $8 / 02$ & $\begin{array}{c}1 \text { group of larvae } \\
25 \text { spat }\end{array}$ & 0 & nd \\
\hline Fort Pierce, Florida & FL-1 & & 23 spat & 0 & nd \\
\hline Gloucester Point, Virginia & VA-1 & $7 / 02$ & 7 groups of larvae $\mathrm{e}^{\mathrm{e}}$ & 0 & nd \\
\hline Muscongus Bay, Maine & $\begin{array}{l}\text { ME-1 } \\
\text { ME-2 }\end{array}$ & $\begin{array}{c}5-7 / 02 \\
7 / 02\end{array}$ & $\begin{array}{l}44 \text { spat } \\
10 \text { spat }\end{array}$ & $\begin{array}{l}0 \\
0\end{array}$ & $\begin{array}{l}\text { nd } \\
\text { nd }\end{array}$ \\
\hline
\end{tabular}




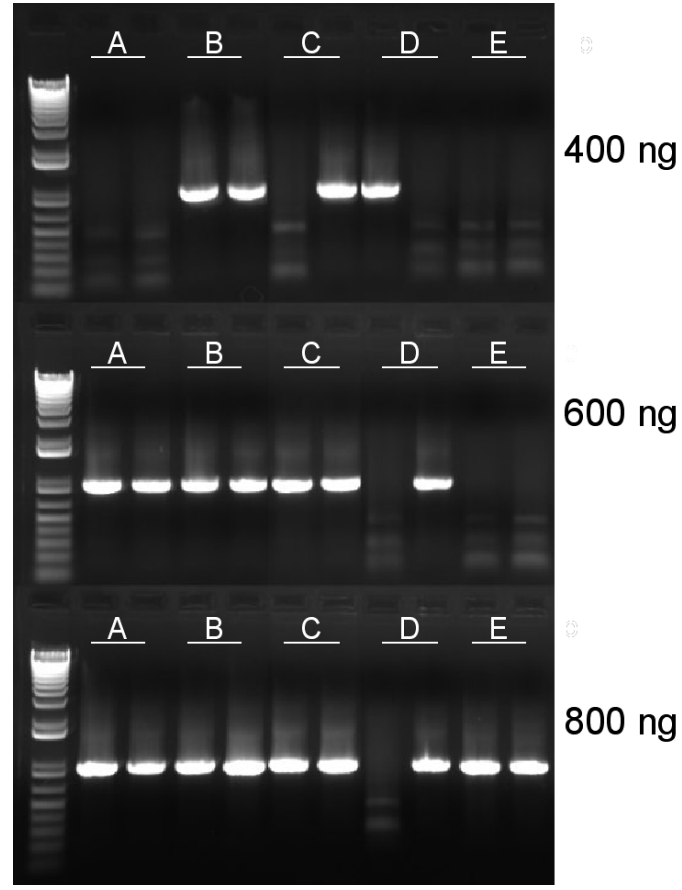

prevalence of OsHV (42\%), while those with higher proportions of dead oysters had higher prevalences of OsHV, as evidenced by PCR analysis (Fig. 1). However, no significant correlation existed between OsHV prevalence and oyster mortality ( $p>0.05$ ) within Tomales Bay, but when all replicate cohorts from Tomales Bay and Totten Inlet, Washington, were examined a significant correlation $(C=0.841$, $\mathrm{p}<0.05)$ was observed. All triploid oysters died in Tomales Bay prior to sampling for OsHV diagnosis. None of the Crassostrea virginica samples, collected from the Atlantic and Gulf coasts, amplified with the A primer set, but all generated amplifiable DNA as evidenced by the presence of the SSU rDNA PCR product. The C primer pair was tested only on sample groups that amplified with the A primers. Since none of the C. virginica samples were PCR positive using primers A5/A6, amplification with primers C2/C6 was not done.

\section{PCR optimization}

Fig. 2 illustrates that increasing the amount of oyster template DNA in the PCR reactions from 50 to $800 \mathrm{ng}$ generally increased the reliability and sensitivity of the assay. However, when over $400 \mathrm{ng}$ of template DNA was used, inhibition was observed in some samples which were initially PCR positive using lower amounts of template DNA and became PCR negative at higher

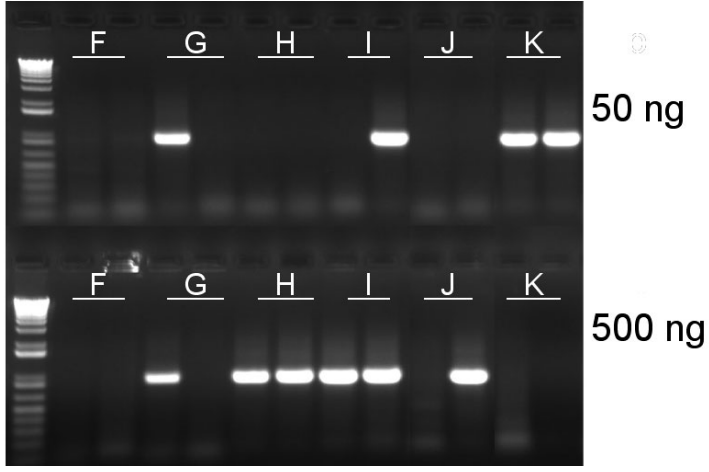

Fig. 2. Optimization of OsHV PCR test using differing amounts of template DNA. Samples were examined in duplicate. Note sample K exhibiting inhibition in a PCR with the higher DNA concentration (500 ng)

template concentrations (Fig. 2, Lane K). Tables 2 \& 3 illustrate the need to examine samples using both $50 \mathrm{ng}$ or $1 \mu \mathrm{l}$ and $500 \mathrm{ng}$ of template nucleic acid. Of the $\sim 72 \%$ of the samples that tested PCR positive, only 18 and $21 \%$ concordance was observed in the PCR tests employing either $50 \mathrm{ng}$ or $1 \mu \mathrm{l}$ and $500 \mathrm{ng}$ of template DNA, respectively.

\section{Sequences}

Sequence analysis indicated that the amplification products from the Californian samples were identical to one another. The 6 French OsHV A3/A4 clones yielded a single consensus sequence of 947 bases, excluding the primer sequences, with no apparent polymorphisms. This was aligned with sequence fragments of the A region previously deposited into GenBank (accession nos. AF173837, AF173838, AJ223507) by Renault et al. (2000a), which comprised 583 bases of the A3/A4 1001 bp amplicon. There were 10 base differences between the sequences generated in this study and those from the earlier work of Renault et al. (2000a).

The herpes-like virus amplified from Pacific oysters in Tomales Bay was similar to that reported by French researchers (Le Deuff \& Renault 1999, Renault et al. 2000a). The consensus sequence was 863 bases long (with primers A5 and A6 removed). The Californian OsHV A fragment sequence was aligned with the French OsHV-1 A fragment sequence generated for this study. The consensus sequences were identical except for 1 transition: base 604 of Californian OsHV was a ' $\mathrm{C}$ ' (in all 20 clones from 12 different samples), while French OsHV-1 had a ' $\mathrm{T}$ ' at this site in all 6 clones examined. 
Table 2. PCR examination of 60 Tomales Bay Pacific oysters using differing template quantities to evaluate the utility of employing either only 50 or $500 \mathrm{ng}$ of nucleic acid or both concentrations in duplicate reactions. na: not applicable

\begin{tabular}{|lcccc|}
\hline & $50 \mathrm{ng}$ & $500 \mathrm{ng}$ & 50 and 500 ng & Total \\
\hline Positive (\%) & 17 & 38 & 18 & 73 \\
Negative (\%) & 83 & 62 & na & 27 \\
\hline
\end{tabular}

Table 3. PCR examination of 89 Tomales Bay Pacific oysters using the standard volume $(1 \mu \mathrm{l})$ employed by Renault et al. (2000b) and $500 \mathrm{ng}$ of nucleic acid template, or both amounts of template. na: not applicable

\begin{tabular}{|lcccc|}
\hline & $1 \mu \mathrm{l}$ & $500 \mathrm{ng}$ & $1 \mu \mathrm{l}$ and 500 ng & Total \\
\hline Positive (\%) & 9 & 38 & 21 & 68 \\
Negative (\%) & 91 & 62 & na & 32 \\
\hline
\end{tabular}

\section{Histology}

Six Pacific oysters confirmed positive for OsHV by PCR were examined histologically, as well as more than 20 other individuals planted in Tomales Bay as part of the study. No evidence of herpes-like intranuclear inclusion bodies was found in any of the oysters. However, most oysters had hemocytes with pycnotic nuclei or nuclear fragmentation (Fig. 3). Affected hemocytes were scattered throughout the organs of the oysters but were not abundant. In addition, several individuals had areas of mantle epithelium in which numerous necrotic cells, presumed to be dead hemocytes, were in the process of diapedesis (Fig. 4). A few

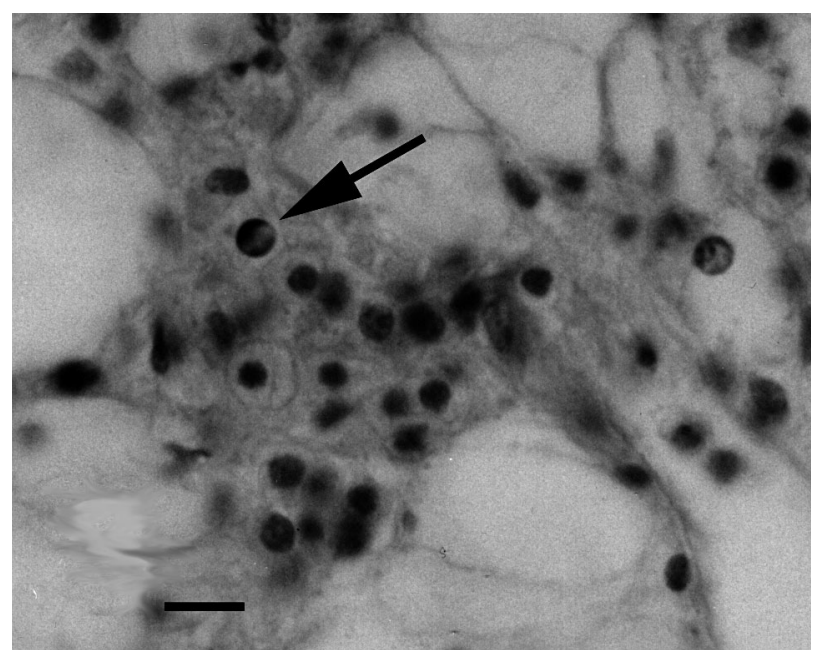

Fig. 3. Pycnotic hemocyte in vascular channel of herpes virus positive oyster (arrow). Scale bar $=10 \mu \mathrm{m}$

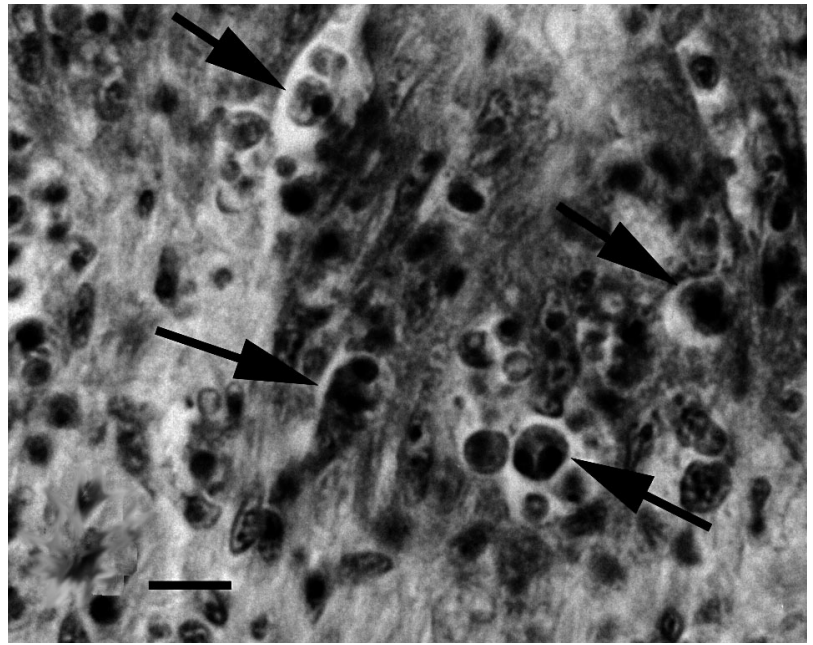

Fig. 4. Host cells with karyorrhectic or pycnotic nuclei in the process of diapedesis in mantle epithelium (arrows) of oyster positive for herpes virus. Scale bar $=10 \mu \mathrm{m}$

of the oysters had mild to moderate hemocytosis in the interstitial area of the digestive gland tubules. No pathogens were associated with these lesions.

\section{DISCUSSION}

Davison (2002) examined currently identified herpes and herpes-like viruses and suggested that the OsHV1 is a member of the Herpesviridae ancestral to all other herpes viruses. The presence of a herpesvirus in Pacific oysters in Tomales Bay, California, that is similar to that reported in France indicates that the geographic distribution of these organisms is wider than previously described (Hine et al. 1992, Renault et al. 1994a,b, 2001, Renault \& Arzul 2001, Arzul et al. 2001, 2002). However, based on our preliminary assessment of Pacific oysters along the west coast of the USA and eastern oysters on the east and Gulf coasts of the USA, the distribution of this virus may be limited to Tomales Bay, where Pacific oysters have suffered from unexplained mass mortalities since 1993 (Cherr \& Friedman 1998, R. A. Elston pers. obs.). These losses were usually associated with elevated seawater temperatures and periodically occurred during phytoplankton blooms (Righetti 2002). During these mortality periods maximum temperatures often exceeded $25^{\circ} \mathrm{C}$ with a mean temperature of $20^{\circ} \mathrm{C}$ (C. S. Friedman \& C. A. Burge unpubl. obs.); such temperatures are associated with OsHV-1 infections in France (Renault et al. 1995, Le Deuff et al. 1996). Recent observations question the role of phytoplankton blooms in these losses (Righetti 2002). 
OsHV prevalences in surviving Tomales Bay oysters roughly corresponded to the proportion of dead oysters within our samples. When we included cohort oysters planted in Washington state (D. Cheney \& A. Suhrbier pers. comm.) where no OsHV was observed, a significant correlation between OsHV prevalence and oyster losses was observed (Table 1). This observation suggests a possible role of the OsHV in Pacific oyster seed mortalities observed each summer since 1993 in Tomales Bay (Cherr \& Friedman 1998) under conditions similar to those described for losses of French oysters (Renault et al. 1994b, 1995). The relationship between the herpes-like virus infection and juvenile Pacific oyster mortalities requires further examination before it can be definitively assigned as the cause of oyster deaths. Our data also illustrate the necessity to evaluate samples using both $1 \mu \mathrm{l}$ (or $50 \mathrm{ng}$ ) and $500 \mathrm{ng}$ of template nucleic acid as use of only one template amount would result in an underrepresentation of the true prevalence of OsHV infection based on PCR examination. Only $\sim 20 \%$ of the Tomales Bay samples tested positive using both template quantities (Tables $2 \& 3$ ).

Interestingly, the OsHV found in Tomales Bay oysters was amplified by the nested A primers but not by primers $\mathrm{C} 2 / \mathrm{C} 6$, unlike the OsHV-1 characterized from France which amplified with both primer sets (Renault et al. 2000b). Arzul et al. (2001) described a variant of the oyster herpes virus, which they found in Crassostrea gigas and Venerupis philippinarum samples from one French hatchery in Normandy. This OsHV-1 variant was amplified by primers A3/A4 consistently, while primers $\mathrm{C} 1 / \mathrm{C} 6$, the forward primer of which targets a region about 180 bases upstream of $\mathrm{C} 2$, resulted in inconsistent amplification. However, amplification using primers $\mathrm{C} 2 / \mathrm{C} 6$ resulted in an amplification product that was $180 \mathrm{bp}$ smaller than their reference OsHV-1 nucleic acid. This is a result of a $200 \mathrm{bp}$ deletion and $27 \mathrm{bp}$ insertion near the C2 sequence of the OsHV-1 genome (Arzul et al. 2001). Additionally, partial sequencing of the A region PCR product of the French OsHV-1 variant revealed a single nucleotide substitution compared to the reference sample (Arzul et al. 2001). This may be comparable to the single transition at base 604 of the A5/6 sequence for the Californian OsHV from C. gigas in this study. Unfortunately, the location and identity of the substitution in the French OsHV-1 variant was not reported; thus the relationship between the Californian OsHV and the OsHV-1 reported from France warrants further elucidation.

Cowdry type A inclusions, consisting of large intranuclear inclusion bodies, are a feature of many herpes-virus infections. They are found in larval Pacific oysters infected with OsHV-1 (Hine et al. 1992,
Renault et al. 1994a) and, according to Renault et al. (1994b), in juvenile Pacific oysters as well. Few published photomicrographs of the histological appearance of these inclusion bodies in larval oysters (Elston 1999) or juvenile oysters exist. Several authors (Renault et al. 1994a,b, Hine \& Thorne 1997, Hine et al. 1998) using transmission electron microscopy have clearly illustrated the presence of productive OsHV infections (formation of complete viral particles) and associated nuclear changes including hypertrophy, chromatin margination and condensation. Renault et al. $(1994 a, b)$ further described enlarged nuclei in larvae and spat as the primary histological manifestation of infection but no histological photomicrographs were provided. Presumably, if OsHV infections result in Cowdry type A inclusion bodies as has been documented by these authors in larvae, the same lesion should be found in juvenile oysters. However, we were unable to find such inclusion bodies in oysters planted in Tomales Bay as part of this study, even though the oysters were confirmed OsHV positive by PCR. The failure to observe such lesions in this study could be the result of temperatures that did not reach a level high enough to permit a productive infection to occur at the time of sampling, although such temperatures may have occurred earlier during the mortality event. Alternatively, although oysters were positive for OsHV in this study, they represented survivors of the mortality event and may have some innate resistance to the infection.

Histological examination of oysters in this study did indicate the presence of potentially significant lesions that may be the result of OsHV infection, namely the occurrence of dying and necrotic (characterized by nuclear pycnosis and fragmentation) hemocytes in the circulatory system and within mantle epithelium, in the process of diapedesis. The nuclear changes observed in association with OsHV infections are often associated with viral-induced apoptosis (Hengartner 2000). The infection of hemocytes by OsHV is consistent with the suggestions of previous authors (Hine et al. 1992, Renault et al. 1994b), although other cell types including 'fibroblasts', and myocytes were suggested as target cell types. Comps \& Cochennec (1993) also observed hemocytosis in the interstitial area of the digestive gland tubules within European flat oysters infected with OsHV. There is a need to define the pathogenesis of the disease in more detail with definitive determination of all target cell types. If hemocytes are a target cell type, as this study suggested, infected oysters may lose a functional self-defense response as the infection progresses. As a result, they may become infected with other opportunistic pathogens, to which they would normally be refractive. However, under the burden 
of OsHV infection such opportunists become the proximal cause of death. Although this condition has been reported in herpes-like infected oyster larvae that are co-infected with bacteria (Elston 1999), no potential pathogens were observed in the oysters examined herein.

Whether or not OsHV infection can cause significant juvenile oyster morbidity or mortality at environmental temperatures that allow productive infection needs to be addressed. It seems unlikely that the oysters would receive a sufficient dose from an external source to infect enough cells without replication of the virus in the oyster and the progressive infection of more and more cells. On the other hand, cells that are infected without the completion of viral particles appear to have significant nuclear damage leading to cell death. In our study, it is possible that temperatures reached a level to permit productive infection during the summer season but had cooled below this temperature by the time the infected survivors were sampled for this study and, thus, we were unable to find typical Cowdry type A inclusion bodies.

The apparent limited distribution of the OsHV in the USA in Tomales Bay, California, combined with its pathogenicity for young oysters highlights the need for careful and thorough health assessments prior to movement of Pacific oysters between aquaculture facilities or embayments. The demonstration of latent OsHV infections in adult oysters (Hine \& Thorne 1997, Hine et al. 1998) and vertical transmission of this virus (Arzul et al. 2002) provides further evidence for proper management of this pathogen within the oyster culture industry. The role of the OsHV in juvenile Pacific oyster mortalities is currently being further examined using a combination of laboratory and field studies. In addition, surveys of other USA coastal areas for OsHV infection are ongoing.

Acknowledgements. We are grateful to the Florida, Louisiana, Maine, Virginia and Washington state oyster growers, and Oregon State University's Molluscan Broodstock Program for providing experimental oysters. We are also grateful to the oyster growers in Tomales Bay, California, for providing experimental space. We thank F. Griffin, K. Menard, D. Cheney and A. Suhrbier for assistance in collecting oysters in California. We also appreciate the insightful comments from the anonymous reviewers of this manuscript. Research was supported by grant number NA16RG1668 from the National Sea Grant College Program, National Oyster Disease Research Program, National Oceanic and Atmospheric Administration, US Department of Commerce, to the Pacific Shellfish Institute, Olympia, Washington. The views expressed herein are those of the authors and do not necessarily reflect the views of NOAA or any of its sub-agencies. The US government is authorized to reproduce this material and distribute for governmental purposes. VIMS contribution number 2634 .

\section{LITERATURE CITED}

Altschul SF, Gish W, Miller W, Myers EW, Lipman DJ (1990) Basic local alignment search tool. J Mol Biol 215(3): 403-410

Arzul I, Renault T, Lipart C, Davison AJ (2001) Evidence for interspecies transmission of oyster herpes virus in marine bivalves. J Gen Virol 82:865-870

Arzul, I, Renault T, Thébault A, Gérard A (2002) Detection of oyster herpesvirus DNA and proteins in asymptomatic Crassostrea gigas adults. Virus Res 84:151-160

Cherr GN, Friedman CS (1998) Investigation of a mass mortality of Pacific oysters, Crassostrea gigas, in Tomales Bay, California. In: California Sea Grant Report of Completed Projects 1994-97, California Sea Grant College Program, La Jolla, CA, p 176-172

Comps M, Cochennec N (1993) A herpes-like virus from the European oyster Ostrea edulis L. J Invertebr Pathol 62: 201-203

Davison AJ (2002) Evolution of herpesviruses. Vet Microbiol 86:69-88

Elston R (1999) Health management, development and histology of seed oysters. World Aquaculture Society, Baton Rouge, LA, p 71-74

Farley CA, Banfield WG, Kasnic G Jr, Foster WS (1972) Oyster herpes-type virus. Science 178:759-760

Hengartner MO (2000) The biochemistry of apoptosis. Nature 407:770-776

Hine PM, Thorne T (1997) Replication of herpes-like viruses in haemocytes of adult flat oysters Ostrea angasi: an ultrastructural study. Dis Aquat Org 29:189-196

Hine PM, Wesney B, Hay BE (1992) Herpes viruses associated with mortalities among hatchery-reared larval Pacific oysters, Crassostrea gigas. Dis Aquat Org 12:135-142

Hine PM, Wesney B, Besant P (1998) Replication of a herpeslike virus in larvae of the flat oyster Tiostrea chilensis at ambient temperature. Dis Aquat Org 32:161-171

Le Deuff R, Renault T (1999) Purification and partial genome characterization of a herpes-like virus infecting the Japanese oyster, Crassostrea gigas. J Gen Virol 80: 1317-1322

Le Deuff RM, Nicolas JL, Renault T, Cochennec N (1994) Experimental transmission of a herpes-like virus to axenic larvae of Pacific oyster, Crassostrea gigas. Bull Eur Assoc Fish Pathol 14(2):69-71

Le Deuff R, Renault T, Gerard A (1996) Effects of temperature on herpes-like virus detection among hatchery reared larval Pacific oysters Crassostrea gigas. Dis Aquat Org 24: 149-157

Le Roux F, Audemard C, Barnaud A, Berthe F (1999) DNA probes as potential tools for the detection of Marteilia refringes. Mar Biotechnol 1:588-597

Luna LG (ed) (1968) Manual of histologic staining methods of the armed forces institute of pathology, 3rd edn. McGrawHill, New York, p 38-39

Nicolas JL, Comps M, Cochennec N (1992) Herpes-like virus infecting Pacific oyster larvae, Crassostrea gigas. Bull Eur Assoc Fish Pathol 12(1):11-13

Renault T, Arzul I (2001) Herpes-like infections in hatcheryreared bivalve larvae in Europe: specific viral DNA detection by PCR. J Fish Dis 24:161-167

Renault T, Le Deuff RM, Cochennec N, Maffart P (1994a) Herpesviruses associated with mortalities among Pacific oyster, Crassostrea gigas, in France-comparative study. Rev Méd Vét 145(10):735-742

Renault T, Cochennec N, Le Deuff RM, Chollet B (1994b) Herpes-like virus infecting Japanese oyster (Crassostrea 
gigas) spat. Bull Eur Assoc Fish Pathol 14(2):64-66

Renault T, Le Deuff RM, Cochennec N, Chollet B, Maffart P (1995) Herpes-like viruses associated with high mortality levels in larvae and spat of Pacific oysters, Crassosstrea gigas: a comparative study, the thermal effects on virus detection in hatchery reared larvae, reproduction of the disease in axenic larvae. Vet Res 26:539-543

Renault T, Le Deuff RM, Chollet B, Cochennec N, Gerard A (2000a) Concomitant herpes-like virus infections in hatchery-reared larvae and nursery-cultured spat Crassostrea gigas and Ostrea edulis. Dis Aquat Org 42: 173-183

Renault T, Le Deuff RM, Lipart C, Delsert D (2000b) Development of a PCR procedure for the detection of a herpes-

Editorial responsibility: Albert Sparks,

Seattle, Washington, USA like virus infecting oysters in France. J Virol Methods 88: $41-50$

Renault T, Lipart C, Arzul I (2001) A herpes-like virus infecting Crassostrea gigas and Ruditapes philippinarum larvae in France. J Fish Dis 24:369-376

Righetti LR (2002) Phytoplankton community structure and seasonal succession in Tomales Bay, California. MS thesis, San Francisco State University, San Francisco, CA

Sambrook J, Fritsch EF, Maniatis T (1989) Molecular cloning: a laboratory manual, 2nd edn. Cold Spring Harbor Laboratory Press, New York

Shaw BL, Battle HI (1957) The gross and microscopic anatomy of the digestive tract of the oyster, Crassostrea virginica (Gmelin). Can J Zool 35:325-347

Submitted: November 22, 2003; Accepted: August 18, 2004

Proofs received from author(s): November 25, 2004 